\title{
Selection and Screening of Superior Genotypes for Quality Planting Stock Based on Vegetative Growth Performance of Some Selected 12-Year-Old Acacia Species
}

\author{
M. Sures Kumar ${ }^{*}$, N. Parameswari ${ }^{2}$, C. F. Chin ${ }^{3}$, Z. Baharum ${ }^{4}$, K. K. Olalekan, \\ A. S. Nor Aini ${ }^{1,4^{*}}$ \\ ${ }^{1}$ Department of Forest Management, Faculty of Forestry, Universiti Putra Malaysia, Serdang, Malaysia \\ ${ }^{2}$ Department of Cell and Molecular Biology, Faculty of Biotechnology and Biomolecular Sciences, \\ Universiti Putra Malaysia, Serdang, Malaysia \\ ${ }^{3}$ School of Biosciences, Faculty of Science, University of Nottingham Malaysia Campus, Semenyih, Malaysia \\ ${ }^{4}$ Institute of Tropical Forestry and Forest Product, Universiti Putra Malaysia, Serdang, Malaysia \\ ${ }^{5}$ Institute of Tropical Agriculture, Universiti Putra Malaysia, Serdang, Malaysia \\ Email: *anishukor@yahoo.com, "smallmammal2006@yahoo.com
}

Received 21 December 2015; accepted 26 June 2016; published 29 June 2016

Copyright (C) 2016 by authors and Scientific Research Publishing Inc.

This work is licensed under the Creative Commons Attribution International License (CC BY).

http://creativecommons.org/licenses/by/4.0/

(c) (7)

Open Access

\section{Abstract}

Production of quality wood is a big problem in forestry plantation since trees grown in plantation of some high value temperate and tropical hardwood species tend to produce low value, short butt logs and bolts due to crooked stems, low fork heights and delayed shedding of lower branches. Result from existing Acacia plantation in Malaysia indicated that most existing Acacia plantation trees especially Acacia auriculiformis and Acacia mangium, fork very heavily which leads to the formation of multiple leaders more than one and some are fork so close to the ground that they will produce little to no merchantable wood. In this context, a research study was initiated to select and recommend the best performing tree species or provenance suited for timber production in Malaysia with respect to growth and other characteristics. Species/provenance/progeny test was conducted on four species of Acacia namely, A. mangium, A. auriculiformis, A. crassicarpa and A. aulococarpa, each with 4 provenances originated from Papua New Guinea (PNG) and Queensland (QL). The growth performance of the provenances was monitored in terms of some quantitative and qualitative characteristics to evaluate the genetic variation and growth performance of a base breeding population. 20 progenies for each species were selected and randomly planted with 16 trees representing each progenies in a trial plot laid out in a randomized complete block

\footnotetext{
"Corresponding author.
} 
design consisting of four blocks as replication. The study showed that there were significant different $(p<0.05)$ between species, provenance and progenies for their growth performance. Generally with regard to growth, $A$. mangium performed better compared to other Acacia species in all of the aspect tested and it was followed by A. crassicarpa, A. aulococarpa and A. auriculiformis. There were also significant differences between provenance within regions and progenies within provenances in all quantitative and qualitative traits tested in this study. Generally, provenance and progenies selected from PNG excelled those from QL both in quantitative and qualitative characteristics. The top performing progenies of Acacia species are CG 1854 of (Bensbach WP) and KN000107 (SW of Boset WP) of A. mangium, BVG2609 (Bensbach WP) of $A$. crassicarpa, BVG 00835 (WP Morehead) and MM1016 (Arufi E Morehead WP) of A. aulococarpa and JSL363 (Wenlock River) and BVG 2657 (Bansbach) of $A$. auriculiformis.

\section{Keywords}

\section{Growth Performance, Provenance-Progeny Trial, Acacia sp, Tree Improvement, Plantation Management}

\section{Introduction}

Acacia belonging to leguminous family, a native of Papua New Guinea, Islands of Torres Strait and northern Australia is a fast growing vigorous tree species. Acacia species are considered as one of the most promising plantation species because of its ability to thrive on wide range of harsh environmental condition such as on poor soil fertility and extended dry period. It is a multipurpose tree species and has been used as a main plantation tree species for production of pulp and paper (Jahan et al., 2008; Turnbull et al., 1997), sawn wood (Phi et al., 2009) and for rehabilitation purposes in many countries. It has been introduced as advanced plantation species into countries such as Malaysia, Indonesia, Vietnam, India, West and South Africa as well as South America (Phi, 2009; Shukla et al., 2007; Nor aini et al., 1994; Turnbull et al., 1997) for various purposes.

Extensive field studies and intensive research works have therefore been taken in the field of tree improvement to develop genetically superior planting stock of Acacia species for different eco-climatic condition. Genetic combining and selection of superior trees with good characteristic for specific end product has to be taken in order to obtain maximum genetic gain in any clonal plantation forestry programme. Taking these factors into consideration, vegetative propagation in the form of micropropagation and macropropagation offers great potential for mass propagation of superior clones. Optimized propagation protocol along with controlled culture growth believed to produce the next generation of propagules containing high frequency of favouring character genes (provided the gene effects are additive) compared to the one propagated by seeds (Rao, 1992). Adequate protocol for mass propagation of Acacia species has been established and in some cases the tissue cultured plantlet has even been introduced successfully into the field (Griffin et al., 2014; Banerjee, 2013; Ismail et al., 2012; Girijashankar, 2011; Mittal et al., 1989). However, mass propagation cannot be achieved without proper selection of superior genotypes.

Tree breeders generally and most often relied on testing species, provenance and progeny to select large number of genotypes derived from different genetic backgrounds, for maintenance of high genetic variation in production forests, sexual propagation and to capture of additive genetic variation through recurrent selection (Strauss et al., 1992; Butcher \& Southerton, 2007). A problem which comes as an important factor in the selection and assessment of the quality of a mother tree is finding clearly definable and easily measureable characteristics by means of objective measure of the tree's usefulness for various purpose. Selection in forest tree breeding is a very important process to capture certain individual trees with some certain desirable traits in it and to increase quantity and quality of wood products from plantation. Tree breeders tend to select individuals by various means in tree breeding programmes to improve a certain traits of a tree according to specific selection criteria and it totally depends on the objective of the selection being made.

Tree breeders use various factors in the selection process in order to completely capture the genetic gain of a particular species. Some important factors include the value of phenotypic variation of trees from selected par- 
ents, value of the selection intensity and the value of the heritability (Williams \& Matheson, 1994). In this context, it is important to obtain appropriate measures of the parent tree's quality. Selected individuals can only be exploited effectively if the selection is aimed at selecting parents for specific crosses that will produce desirable progeny, or if vegetative propagation is used to clone individuals to capture the entire attributes of desired phenotype or genotypes.

Before any tree improvement programme or breeding can be done, in large scale, suitable species, provenance and progeny for a particular locality should be selected and their growth performance also need to be assessed to evaluate various genotypes at different altitudes and establishment of seed stands. This is because different genotype performs differently to different environmental condition due to their variation in genetic component and particular geo-climatic regions need to be established for each species, provenance and progeny of the species (Renuka, 2001). Genetic variability among these genotypes constitutes the raw materials for further breeding programmes and the higher variability within a population; the better the chances to select individuals with desirable characteristic. For long term improvement of genetically improved genotype, several provenanceprogeny trials have been established in different part of the world to determine the good performing genotypes for certain environmental condition. High significant differences were found among various provenances tested in terms of growth performances as well as in qualitative characteristics such as stem straightness and shape of bole (Kha, 2003; Mahat, 2007; Phi, 2008, 2009).

The selection of candidate trees is usually based upon various important attributes specifically designed for a certain tree species and their relative ranking. Growth performance of a species normally associated with the increase in yield of wood product. When the objective is to maximize the yield then individual tree height together with their clear bole height and diameter of the bole or volume is the highest priority of growth traits in plus tree selection (Zobel \& Talbert, 1984; Cornelius, 1994). However, selecting only quantitative traits value might not represent the actual performance of an ideal tree taking into consideration that not a single tree simultaneously performs best in respect of all attributes (Gadow \& Bredenkamp, 1992). Some of the ideal selection criterion chosen in the tree improvement program is the straightness, fastest growing and most resistant to disease or pest (Mishra, 2009).

It is a known fact that greater logs with large diameter are easier to quarter-saw with less growth stress problems and produce greater value of sawn timber recovery (Steele, 1984). Taking these factors into consideration, tree improvement programmes aim to maximize production generally consider height and diameter of a tree, stem straightness, shape of the tree bole and tree branching habit to be included in any tree improvement programmes. These traits are related directly to the formation of good quality wood along with considerable clear bole/merchantable height. Straight tree with larger diameter tend to produce larger and good quality logs having less tension wood. Superior genotypes exhibiting good phenotypic characteristic can be selected from large population using morphological variation.

Provenance and progeny trials conducted reveal highly significant genetic variation among materials originating from different region and even between provenance from the same region in terms of growth performance and their qualitative characteristics (Kamis et al., 1994; Nor Aini et al., 1994; Phi, 2008, 2009). Therefore this work has been developed to evaluate the performance of 12-year-old Acacia species through selection and screening of potential mother tree to be used as initial plant source for mass clonal propagation.

\section{Material and Methods}

\subsection{Description of Study Site and Plant Material}

This study focused on the selection of Acacia plus trees for quality planting stock production from three different aspects which is species, provenance and progeny (genotype). There were four different Acacia species involved in the study; A. mangium, A. auriculiformis, A. crassicarpa and A. aulococarpa originated from Queensland (OLD) and Papua New Guinea (PNG). This provenance-progeny trial was established at How Swee Sdn. Bhd. Estate, Kampung Aur Gading, Kuala Lipis, Pahang, Malaysia using seed sources supplied by ACIAR through CSIRO. A progeny trial was established through clear felling of Rubber (Hevea brasiliensis) tree on soil described as deep, brownish yellow to yellowish brown fine sandy loam in 1998. A total of 16 provenances were randomly planted in 4 blocks in Randomized Complete Block Design (RCBD). Each block is made up of 80 lines ( 80 progenies) where each line consisted of 16 individual trees with $3 \mathrm{~m} \times 3 \mathrm{~m}$ spacing. Details of the species, provenance and progenies evaluated in this provenance-progeny trial are summarized in Table 1. 
Table 1. Detail of the 16 provenances of Acacias used in this study.

\begin{tabular}{|c|c|c|c|c|c|c|c|}
\hline Species & $\begin{array}{c}\text { CSIRO } \\
\text { Section No }\end{array}$ & Provenances & Origin & Lat $\left(0^{\circ} \mathrm{S}\right)$ & Long $\left(0^{\circ} \mathrm{E}\right)$ & Alt (m) & No parents \\
\hline \multirow{4}{*}{ A. mangium } & 18,249 & Captain Billy Road (CBR) & QLD & 1141 & 14,242 & 100 & 5 \\
\hline & 18,767 & $\begin{array}{l}\text { Russell \& Gap CK } \\
\text { (R\&GCK) }\end{array}$ & QLD & 1552 & 14,519 & 60 & 7 \\
\hline & 17,550 & Bansbech (B) & PNG & 8503 & 14,117 & 25 & 10 \\
\hline & 18,194 & $\begin{array}{l}\text { SW of Boset WP } \\
\text { (SWBWP) }\end{array}$ & PNG & 7107 & 14,105 & 100 & 5 \\
\hline \multirow{4}{*}{ A. auriculiformis } & 17,966 & Buggy Creek (BC) & QLD & 1552 & 14,453 & 240 & 10 \\
\hline & 18,247 & Wenlock River (WR) & QLD & 1305 & 14,251 & 120 & 30 \\
\hline & 18,924 & Mibini (M) & PNG & 8500 & 14,138 & 18 & 30 \\
\hline & 18,932 & Bansbach (B) & PNG & 8503 & 14,117 & 25 & 20 \\
\hline \multirow{4}{*}{ A. crassicarpa } & 17,944 & Claudie River (CR) & QLD & 1248 & 14,318 & 20 & 4 \\
\hline & 17,948 & Chilli Beach (CR) & QLD & 1238 & 14,323 & 3 & 10 \\
\hline & 18,940 & Bimadebum WP (BMWP) & PNG & 8308 & 14,203 & 40 & 50 \\
\hline & 18,947 & Bensbach WP (BWP) & PNG & 8503 & 14,117 & 25 & 49 \\
\hline \multirow{4}{*}{ A. aulococarpa } & 17,739 & 3K S Mt Larcom (3KSML) & QLD & 2305 & 15,100 & 70 & 11 \\
\hline & 17,891 & Samford (S) & QLD & 2717 & 15,251 & 50 & 5 \\
\hline & 16,112 & W Morehead (WM) & PNG & 8402 & 14,134 & 30 & 14 \\
\hline & 16,995 & $\begin{array}{l}\text { Arufi E Morehead WP } \\
\text { (AEMWP) }\end{array}$ & PNG & 8403 & 14,155 & 25 & 150 \\
\hline
\end{tabular}

\subsection{Quantitative and Qualitative Traits Assessment}

All trees in the trial plot were evaluated based on their quantitative and qualitative traits. Quantitative traits such as diameter at breast height (DBH) and height were measured and compared with the mean diameter and height of each species separately. Some of the qualitative traits that considered for plus tree selection are i.e. crown emergence, crown diameter, crown form, stem straightness, branching and forking system, branching quality and quantity, axis of branches and pruning ability were also be taken from potential plus trees. From these data, a second screening based on both traits will be made. Evaluation of the qualitative traits was done in descending order using a scoring system where an individual tree was given rank according to their superiority for a certain characteristic (Cotterill \& Dean, 1990). Trees having best phenotype for a certain growth trait was given highest rank and followed by non-favorable phenotype (6 for the best). Quantitative and qualitative traits selected to assess the variation among trees are listed below.

- Diameter at breast height (DBH) - Diameter of the tree stem at breast height (=1.3 $\mathrm{m}$ above the ground)

- Height $(\mathrm{H})$ - Total height of the tree from above the ground to the top of the tree

- Clear bole height/merchantable height $(\mathrm{CBH})$ - height of the tree from the ground to the first branch of the crown

- Crown size (CS) - Diameter of the crown (length from outermost branch of the crown from one end to the other on ground level)

- Number of stem (NS) - Number of stem produced from the base of the tree trunk.

- The bole form (BF) score categories (six-point score) - 6(circular/round in cross section) to 1 (severe flute and excessive taper)

- The stem straightness (SS) score categories (six-point score) - 6 (very straight) to 1 (crooked with severe bends and kinks)

- The forking ability (FA) score categories (six-point score) - 6 (single stem), 5 (fork $>6 \mathrm{~m}$ ), 4 (fork at 4 - 6 
$\mathrm{m}), 3$ (fork at $2-4 \mathrm{~m}$ ), 2 (fork $<2 \mathrm{~m}$ ) and 1(multiple leader)

- The branch size (BS) score categories (four-point score) $-4(<1 / 4$ of the main stem), $3(1 / 4$ to $1 / 2$ of the main stem), 2 (between $1 / 2$ to $3 / 4$ of the main stem) and 1 (between $3 / 4$ to 1 of the main stem)

- The branch angle (BA) score categories (four-point score) - 4 (angle between $65^{\circ}$ to $90^{\circ}$ to the main stem), 3 (angle between $45^{\circ}$ to $65^{\circ}$ to the main stem), 2 (angle between $25^{\circ}$ to $45^{\circ}$ to the main stem) and 1 (angle < $25^{\circ}$ to the main stem)

\section{Result and Discussion}

Studies conducted on the growth performance of Acacia species revealed a clear variation and differences in morphological characters among species, provenances and families especially those obtained from a wide range of natural distribution (Wright, 1976; Anoop et al., 2012). A study of genetic variation from a wide range of distribution among species and origin of genotypes can assist in selecting the best genotypes for more advanced breeding program. The establishment of growth trials to evaluate growth performance both on quantitative and qualitative traits is an initial stage in any tree improvement programme for large scale plantation establishment. Similarly, the establishment of a trial plot in this study also found a wide significant variation among four different species originating from different seed sources from two regions namely Papua New Guinea (PNG) and Queensland (QLD). Overall, this study found significant variation between block, region, provenance and progeny for all quantitative traits studied except for number of stem (NS) for all species, and for diameter at breast height (DBH) and crown size (CS) for A. crassicarpa (Table 2). On the other end, there was no significant difference among most sources of variation in all species level for the qualitative traits especially for branch size (BS) and branch angle (BA). Significant differences at $p \leq 0.05$ were detected for all quantitative growth traits measures at geographic region level for all species. Generally, the mean values for all quantitative growth traits of provenances from PNG were significantly higher compared to the mean values obtained from the ones from the QLD region except for NS.

In contrast, average of $A$. mangium from the QLD region were higher for all qualitative growth traits compared to the ones from the PNG region but the trend was opposite for A. crassicarpa where the PNG region outperformed the QLD region for all qualitative traits studied. The performance of both A. auriculiformis for qualitative traits is inconsistent in terms of geographic region (Table 3). Overall, PNG genotypes outperformed the QLD genotypes. Papua New Guinea (PNG), Queensland (QLD) and Northern Territory (NT) are three of the most common native geographic regions of seed sources used in most of the studies to evaluate the growth performance of Acacia species from Australia. Provenance trials originating from different regions conducted in several countries have found significant variation in growth performance both in terms of quantitative and qualitative traits (Senin et al., 2011; Phi, 2009 for A. auriculiformis; Nghia, 2003 for A. Kao; Luangviriyasaeng and Pinyopusarerk, 2002; Kamis et al., 1994; Nor Aini et al., 1994 for A. auriculiformis; Kamis et al., 1995 for A. crassicarpa). Several studies conducted in Malaysia found that PNG outperformed than the ones from other regions (Kamis et al., 1994; Nor Aini et al., 1994 for A. auriculiformis and Mahat, 2007 for A. mangium, A. auriculiformis, A. crassicarpa and A. aulococarpa).

Multi-locational international provenance trials conducted at 19 sites of Southeast and South Asia, Australia and Fiji consisted of PNG, QLD, Far North QLD, Cream and Irian Jaya found that PNG provenances performed consistently better than the others (Harwood \& William, 1992). The potential of Acacia plantation establishment in terms of productivity using seed sources from PNG provenances of A. crassicarpa and A. mangium and QLD provenances of A.auriculiformis has been highlighted in previous study conducted by Otsamo et al., (1996). A . auriculiformis which is well known for its poor form and incidence of unacceptable forking in the lower part (Nor Aini et al., 1994), but wood produced from selected seed sources of PNG were found to have excellent potentials for pulpwood and it was also as good as the high quality pulp wood of Eucalyptus (Indira, 1999; Logan, 1987). Growth performance of provenance Wipim from PNG grown in Indonesia was reported to be 70-80 \% greater than its local Indonesia provenance, Subanjeriji (Turvey, 1996). Differences in the growth variation among regions and provenances indicate the importance of the establishment of trial plots before the establishment of breeding population and production population. Variation in growth performance also can be clearly seen from other Acacia species where the overall performance of A. mangium was significantly different and better compared to the performance of other Acacia species (Table 4). A. mangium outgrew than other three Acacia species in almost all quantitative growth traits tested except for NS. Number of stem (NS) of the Acacia 
Table 2. Analysis of variance for quantitative and qualitative growth traits of four 12-year old Acacia species.

\begin{tabular}{|c|c|c|c|c|c|c|c|c|c|c|c|c|}
\hline Species & $\begin{array}{l}\text { Source of } \\
\text { variation }\end{array}$ & df & $\begin{array}{l}\mathrm{H} \\
(\mathrm{m})\end{array}$ & $\begin{array}{l}\mathrm{CBH} \\
(\mathrm{m})\end{array}$ & $\begin{array}{l}\text { DBH } \\
(\mathrm{cm})\end{array}$ & $\begin{array}{l}\text { CS } \\
(\mathrm{m})\end{array}$ & NS & $\mathrm{BF}$ & SS & FA & BS & BA \\
\hline \multirow{4}{*}{$\begin{array}{c}\text { Acacia } \\
\text { mangium }\end{array}$} & Block & 1 & $39.32^{*}$ & $60.71^{*}$ & $108.92^{*}$ & $41.07^{*}$ & $7.64^{*}$ & $0.00^{\text {ns }}$ & $0.51^{\mathrm{ns}}$ & $6.41^{*}$ & $2.84^{\mathrm{ns}}$ & $2.13^{\text {ns }}$ \\
\hline & Region & 1 & $10.02^{*}$ & $19.10^{*}$ & $41.38^{*}$ & $10.95^{*}$ & $1.01^{\mathrm{ns}}$ & $5.94^{*}$ & $0.12^{\mathrm{ns}}$ & $0.00^{\mathrm{ns}}$ & $0.26^{\mathrm{ns}}$ & $0.15^{\mathrm{ns}}$ \\
\hline & Provenance & 3 & $16.51^{*}$ & $15.13^{*}$ & $14.70^{*}$ & $6.30^{*}$ & $3.67^{*}$ & $6.52^{*}$ & $6.20^{*}$ & $1.89^{\mathrm{ns}}$ & $4.88^{*}$ & $2.23^{\mathrm{ns}}$ \\
\hline & Progeny & 19 & $4.28^{*}$ & $4.32^{*}$ & $4.51^{*}$ & $3.37^{*}$ & $1.87^{*}$ & $3.50^{*}$ & $3.37^{*}$ & $2.40^{*}$ & $2.65^{*}$ & $1.59^{\text {ns }}$ \\
\hline \multirow{4}{*}{$\begin{array}{c}\text { Acacia } \\
\text { auriculiformis }\end{array}$} & Block & 1 & $93.8^{*}$ & $71.3^{*}$ & $32.96^{*}$ & $29.29^{*}$ & $0.06^{\mathrm{ns}}$ & $1.96^{\mathrm{ns}}$ & $40.56^{*}$ & $4.30^{*}$ & $0.49^{\text {ns }}$ & $2.13^{\mathrm{ns}}$ \\
\hline & Region & 1 & $151.73^{*}$ & $133.8^{*}$ & $25.96^{*}$ & $10.19^{*}$ & $0.63^{\mathrm{ns}}$ & $5.18^{*}$ & $0.03^{\mathrm{ns}}$ & $0.16^{\mathrm{ns}}$ & $6.25^{*}$ & $2.2^{\mathrm{ns}}$ \\
\hline & Provenance & 3 & $54.35^{*}$ & $49.5^{*}$ & $8.72^{*}$ & $6.54^{*}$ & $1.21^{\mathrm{ns}}$ & $5.21^{*}$ & $2.78^{*}$ & $0.39^{\text {ns }}$ & $2.40^{\mathrm{ns}}$ & $1.18^{\mathrm{ns}}$ \\
\hline & Progeny & 19 & $12.91^{*}$ & $11.99^{*}$ & $5.41^{*}$ & $2.54^{*}$ & $1.07^{\mathrm{ns}}$ & $5.18^{*}$ & $4.13^{*}$ & $2.44^{*}$ & $3.21^{*}$ & $0.77^{\mathrm{ns}}$ \\
\hline \multirow{4}{*}{$\begin{array}{c}\text { Acacia } \\
\text { crassicarpa }\end{array}$} & Block & 1 & $48.27^{*}$ & $45.49^{*}$ & $0.00^{\mathrm{ns}}$ & $0.62^{\mathrm{ns}}$ & $22.09^{*}$ & $12.33^{*}$ & $29.17^{*}$ & $15.51^{*}$ & $8.95^{*}$ & $0.19^{\text {ns }}$ \\
\hline & Region & 1 & $14.44^{*}$ & $14.28^{*}$ & $17.37^{*}$ & $4.17^{*}$ & $3.51^{\mathrm{ns}}$ & $0.34^{\mathrm{ns}}$ & $5.19^{*}$ & $2.34^{\mathrm{ns}}$ & $1.21^{\mathrm{ns}}$ & $0.08^{\text {ns }}$ \\
\hline & Provenance & 3 & $5.24^{*}$ & $5.20^{*}$ & $7.78^{*}$ & $1.92^{\mathrm{ns}}$ & $1.97^{\mathrm{ns}}$ & $3.01^{*}$ & $4.65^{*}$ & $2.44^{\mathrm{ns}}$ & $1.06^{\mathrm{ns}}$ & $0.05^{\mathrm{ns}}$ \\
\hline & Progeny & 19 & $4.16^{*}$ & $4.11^{*}$ & $5.80^{*}$ & $2.79^{*}$ & $1.42^{\mathrm{ns}}$ & $2.76^{*}$ & $3.05^{*}$ & $3.00^{*}$ & $3.07^{*}$ & $0.52^{\mathrm{ns}}$ \\
\hline \multirow{4}{*}{$\begin{array}{c}\text { Acacia } \\
\text { aulococarpa }\end{array}$} & Block & 1 & $74.15^{*}$ & $69.87^{*}$ & $32.08^{*}$ & $51.99^{*}$ & $4.87^{*}$ & $13.26^{*}$ & $12.83^{*}$ & $0.60^{\mathrm{ns}}$ & $14.44^{*}$ & $40.71^{*}$ \\
\hline & Region & 1 & $96.67^{*}$ & $100.34^{*}$ & $30.44^{*}$ & $13.73^{*}$ & $4.51^{*}$ & $13.66^{*}$ & $18.68^{*}$ & $32.30^{*}$ & $0.22^{\mathrm{ns}}$ & $3.49^{\mathrm{ns}}$ \\
\hline & Provenance & 3 & $32.08^{*}$ & $33.53^{*}$ & $14.63^{*}$ & $16.59^{*}$ & $1.60^{\mathrm{ns}}$ & $6.28^{*}$ & $8.94^{*}$ & $10.99^{*}$ & $2.43^{\mathrm{ns}}$ & $2.22^{\mathrm{ns}}$ \\
\hline & Progeny & 19 & $10.32^{*}$ & $10.39^{*}$ & $7.00^{*}$ & $5.95^{*}$ & $2.78^{*}$ & $6.17^{*}$ & $4.67^{*}$ & $4.33^{*}$ & $4.11^{*}$ & $1.41^{\mathrm{ns}}$ \\
\hline
\end{tabular}

Note: $\mathrm{H}=$ Height, $\mathrm{CBH}=$ Clear bole height, $\mathrm{DBH}=$ Diameter at breast height, $\mathrm{CS}=$ Crown size, $\mathrm{NS}=$ Number of stem, $\mathrm{BF}=\mathrm{Bole}$ form, $\mathrm{SS}=\mathrm{Stem}$ straightness, $\mathrm{FA}=$ Forking ability, $\mathrm{BS}=\mathrm{Branch}$ size, $\mathrm{BA}=\mathrm{Branch}$ angle; ${ }^{*}$ Significant at $p \leq 0.05$, ns $=$ not significant at $p>0.05$.

Table 3. Mean values for quantitative growth traits in terms of geographic regions of four 12 year old Acacia species.

\begin{tabular}{|c|c|c|c|c|c|c|c|c|c|c|c|}
\hline Species & Region & $\begin{array}{l}\mathrm{H} \\
(\mathrm{m})\end{array}$ & $\begin{array}{l}\mathrm{CBH} \\
(\mathrm{m})\end{array}$ & $\begin{array}{l}\text { DBH } \\
(\mathrm{cm})\end{array}$ & $\begin{array}{l}\text { CS } \\
(\mathrm{m})\end{array}$ & NS & $\mathrm{BF}$ & SS & FA & BS & BA \\
\hline \multirow{2}{*}{$\begin{array}{c}\text { Acacia } \\
\text { mangium }\end{array}$} & PNG & $\begin{array}{c}27.82 \\
\pm 0.42\end{array}$ & $\begin{array}{l}23.66 \\
\pm 0.42\end{array}$ & $\begin{array}{c}25.37 \\
\pm 0.59\end{array}$ & $\begin{array}{c}6.36 \\
\pm 0.15\end{array}$ & $\begin{array}{c}1.30 \\
\pm 0.04\end{array}$ & $\begin{array}{c}4.33 \\
\pm 0.08\end{array}$ & $\begin{array}{c}3.75 \\
\pm 0.09\end{array}$ & $\begin{array}{c}3.43 \\
\pm 0.12\end{array}$ & $\begin{array}{c}3.42 \\
\pm 0.05\end{array}$ & $\begin{array}{c}2.42 \\
\pm 0.05\end{array}$ \\
\hline & QLD & $\begin{array}{l}25.58 \\
\pm 0.58\end{array}$ & $\begin{array}{c}20.60 \\
\pm 0.56\end{array}$ & $\begin{array}{l}19.39 \\
\pm 0.68\end{array}$ & $\begin{array}{c}5.51 \\
\pm 0.21\end{array}$ & $\begin{array}{c}1.24 \\
\pm 0.05\end{array}$ & $\begin{array}{c}4.62 \\
\pm 0.09\end{array}$ & $\begin{array}{c}3.80 \\
\pm 0.12\end{array}$ & $\begin{array}{c}3.44 \\
\pm 0.15\end{array}$ & $\begin{array}{c}3.47 \\
\pm 0.07\end{array}$ & $\begin{array}{c}2.45 \\
\pm 0.07\end{array}$ \\
\hline \multirow{2}{*}{$\begin{array}{c}\text { Acacia } \\
\text { auriculiformis }\end{array}$} & PNG & $\begin{array}{l}21.97 \\
\pm 0.54\end{array}$ & $\begin{array}{r}17.00 \\
\pm 0.52\end{array}$ & $\begin{array}{r}18.63 \\
\pm 0.67\end{array}$ & $\begin{array}{c}4.99 \\
\pm 0.21\end{array}$ & $\begin{array}{c}1.16 \\
\pm 0.03\end{array}$ & $\begin{array}{c}4.40 \\
\pm 0.09\end{array}$ & $\begin{array}{c}3.74 \\
\pm 0.10\end{array}$ & $\begin{array}{c}3.51 \\
\pm 0.12\end{array}$ & $\begin{array}{c}3.58 \\
\pm 0.04\end{array}$ & $\begin{array}{c}2.20 \\
\pm 0.04\end{array}$ \\
\hline & QLD & $\begin{array}{c}13.63 \\
\pm 0.40\end{array}$ & $\begin{array}{c}9.71 \\
\pm 0.35\end{array}$ & $\begin{array}{r}14.00 \\
\pm 0.61\end{array}$ & $\begin{array}{c}4.11 \\
\pm 0.18\end{array}$ & $\begin{array}{c}1.12 \\
\pm 0.03\end{array}$ & $\begin{array}{c}4.68 \\
\pm 0.08\end{array}$ & $\begin{array}{c}3.71 \\
\pm 0.09\end{array}$ & $\begin{array}{c}3.58 \\
\pm 0.12\end{array}$ & $\begin{array}{c}3.39 \\
\pm 0.06\end{array}$ & $\begin{array}{c}2.54 \\
\pm 0.23\end{array}$ \\
\hline \multirow{2}{*}{$\begin{array}{c}\text { Acacia } \\
\text { crassicarpa }\end{array}$} & PNG & $\begin{array}{l}25.71 \\
\pm 0.53\end{array}$ & $\begin{array}{l}20.83 \\
\pm 0.51\end{array}$ & $\begin{array}{l}22.21 \\
\pm 0.58\end{array}$ & $\begin{array}{c}5.87 \\
\pm 0.17\end{array}$ & $\begin{array}{c}1.22 \\
\pm 0.04\end{array}$ & $\begin{array}{c}4.31 \\
\pm 0.09\end{array}$ & $\begin{array}{c}3.67 \\
\pm 0.11\end{array}$ & $\begin{array}{c}3.42 \\
\pm 0.14\end{array}$ & $\begin{array}{c}3.57 \\
\pm 0.06\end{array}$ & $\begin{array}{c}2.40 \\
\pm 0.05\end{array}$ \\
\hline & QLD & $\begin{array}{l}23.01 \\
\pm 0.48\end{array}$ & $\begin{array}{r}18.33 \\
\pm 0.43\end{array}$ & $\begin{array}{l}18.63 \\
\pm 0.56\end{array}$ & $\begin{array}{c}5.41 \\
\pm 0.15\end{array}$ & $\begin{array}{c}1.34 \\
\pm 0.05\end{array}$ & $\begin{array}{c}4.23 \\
\pm 0.09\end{array}$ & $\begin{array}{c}3.32 \\
\pm 0.11\end{array}$ & $\begin{array}{c}3.13 \\
\pm 0.12\end{array}$ & $\begin{array}{c}3.48 \\
\pm 0.05\end{array}$ & $\begin{array}{r}2.38 \\
\pm 0.05\end{array}$ \\
\hline \multirow{2}{*}{$\begin{array}{c}\text { Acacia } \\
\text { aulococarpa }\end{array}$} & PNG & $\begin{array}{l}21.75 \\
\pm 0.44\end{array}$ & $\begin{array}{l}16.92 \\
\pm 0.40\end{array}$ & $\begin{array}{c}19.62 \\
\pm 0.49\end{array}$ & $\begin{array}{c}5.29 \\
\pm 0.14\end{array}$ & $\begin{array}{c}1.20 \\
\pm 0.04\end{array}$ & $\begin{array}{c}4.61 \\
\pm 0.08\end{array}$ & $\begin{array}{c}4.02 \\
\pm 0.10\end{array}$ & $\begin{array}{c}3.97 \\
\pm 0.12\end{array}$ & $\begin{array}{c}3.55 \\
\pm 0.05\end{array}$ & $\begin{array}{c}2.57 \\
\pm 0.06\end{array}$ \\
\hline & QLD & $\begin{array}{c}14.81 \\
\pm 0.57\end{array}$ & $\begin{array}{r}10.44 \\
\pm 0.52\end{array}$ & $\begin{array}{r}14.97 \\
\pm 0.73\end{array}$ & $\begin{array}{c}4.45 \\
\pm 0.19\end{array}$ & $\begin{array}{c}1.33 \\
\pm 0.05\end{array}$ & $\begin{array}{c}4.10 \\
\pm 0.12\end{array}$ & $\begin{array}{c}3.37 \\
\pm 0.12\end{array}$ & $\begin{array}{c}2.96 \\
\pm 0.13\end{array}$ & $\begin{array}{c}3.59 \\
\pm 0.06\end{array}$ & $\begin{array}{c}2.40 \\
\pm 0.06\end{array}$ \\
\hline \multirow{2}{*}{ Total } & PNG & $\begin{array}{c}24.33 \\
\pm 0.26\end{array}$ & $\begin{array}{r}19.67 \\
\pm 0.25\end{array}$ & $\begin{array}{l}21.54 \\
\pm 0.31\end{array}$ & $\begin{array}{c}5.63 \\
\pm 0.09\end{array}$ & $\begin{array}{c}1.22 \\
\pm 0.01\end{array}$ & $\begin{array}{c}4.42 \\
\pm 0.04\end{array}$ & $\begin{array}{c}3.81 \\
\pm 0.05\end{array}$ & $\begin{array}{c}3.59 \\
\pm 0.06\end{array}$ & $\begin{array}{c}3.52 \\
\pm 0.02\end{array}$ & $\begin{array}{c}2.40 \\
\pm 0.03\end{array}$ \\
\hline & QLD & $\begin{array}{l}18.89 \\
\pm 0.32\end{array}$ & $\begin{array}{c}14.44 \\
\pm 0.29\end{array}$ & $\begin{array}{r}16.59 \\
\pm 0.33\end{array}$ & $\begin{array}{c}4.83 \\
\pm 0.09\end{array}$ & $\begin{array}{c}1.26 \\
\pm 0.02\end{array}$ & $\begin{array}{c}4.41 \\
\pm 0.05\end{array}$ & $\begin{array}{c}3.54 \\
\pm 0.05\end{array}$ & $\begin{array}{c}3.28 \\
\pm 0.06\end{array}$ & $\begin{array}{c}3.48 \\
\pm 0.03\end{array}$ & $\begin{array}{c}2.44 \\
\pm 0.07\end{array}$ \\
\hline
\end{tabular}

Note: $\mathrm{H}=$ Height, $\mathrm{CBH}=$ Clear bole height, $\mathrm{DBH}=$ Diameter at breast height, $\mathrm{CS}=$ Crown size, $\mathrm{NS}=\mathrm{Number}$ of $\mathrm{stem}, \mathrm{BF}=\mathrm{Bole}$ form, $\mathrm{SS}=\mathrm{Stem}$ straightness, $\mathrm{FA}=$ Forking ability, $\mathrm{BS}=$ Branch size, $\mathrm{BA}=$ Branch angle. 
Table 4. Mean values of quantitative growth traits of four 12-year-old Acacia species.

\begin{tabular}{cccccc}
\hline Species & $\mathrm{H}(\mathrm{m})$ & $\mathrm{CBH}(\mathrm{m})$ & $\mathrm{DBH}(\mathrm{cm})$ & $\mathrm{CS}(\mathrm{m})$ & NS \\
\hline Acacia mangium & $26.99 \pm 0.35^{\mathrm{a}}$ & $22.53 \pm 0.35^{\mathrm{a}}$ & $23.17 \pm 0.47^{\mathrm{a}}$ & $6.04 \pm 0.13^{\mathrm{a}}$ & $1.28 \pm 0.03^{\mathrm{a}}$ \\
Acacia auriculiformis & $17.94 \pm 3.89^{\mathrm{c}}$ & $13.51 \pm 0.36^{\mathrm{c}}$ & $16.40 \pm 0.47^{\mathrm{c}}$ & $4.56 \pm 0.14^{\mathrm{d}}$ & $1.14 \pm 0.02^{\mathrm{b}}$ \\
Acacia crassicarpa & $24.27 \pm 0.36^{\mathrm{b}}$ & $19.43 \pm 0.34^{\mathrm{b}}$ & $20.21 \pm 0.42^{\mathrm{b}}$ & $5.61 \pm 0.11^{\mathrm{b}}$ & $1.28 \pm 0.03^{\mathrm{a}}$ \\
Acacia aulococarpa & $18.72 \pm 0.39^{\mathrm{c}}$ & $14.09 \pm 0.36^{\mathrm{c}}$ & $17.85 \pm 0.50^{\mathrm{c}}$ & $4.92 \pm 0.12^{\mathrm{c}}$ & $1.26 \pm 0.03^{\mathrm{a}}$ \\
\hline
\end{tabular}

Note: $\mathrm{H}=$ Height, $\mathrm{CBH}=$ Clear bole height, $\mathrm{DBH}=$ Diameter at breast height, $\mathrm{CS}=$ Crown size, $\mathrm{NS}=\mathrm{Number}$ of stem; Values are expressed in Mean \pm Standard Error; Significant differences among species are indicated by different lower case letters $(p<0.05)$.

species grown in this study plot did not reveal any significant difference. A. mangium lead the other species in terms of total height, clear bole height, diameter at breast height and crown size with highest mean value of $26.99 \mathrm{~m}, 22.53 \mathrm{~m}, 23.17 \mathrm{~m}$ and $6.04 \mathrm{~m}$ respectively.

A. mangium which proved to be the best in vegetative growth however did not perform very well in almost all of its qualitative growth traits except for stem straightness (SS). The poor performance of A. auriculiformis might be due to the environmental factor affecting the planting design in this study where progenies of this species were mixed planted and grew side by side with the progenies of other species. A. auriculiformis and A. aulococarpa failed to compete with the other species and performed poorly and was the most inferior species for all quantitative growth traits tested. However, the same species outperformed or was equally superior to the other species in almost all qualitative growth traits assessed with relatively significant higher mean values. The effects of one species on another in mixed plantation which give rise to the confounding effects (effects of one species on growth performance of others in mixed species plantation) have been highlighted in several studies (Mahat, 2007; Kamis et al., 1994; 1995; Nor aini et al., 1994). The actual performance due to the genetic factors may not be clearly seen since the phenotypic variation shown by a particular species might be because of the stress factors caused by neighboring species from the same species or other species (Phi, 2009; McNamara et al., 2006). Mixed planting often establish with species mixture between a taller, thinner crown and fast growing light demanding species and a slow growing shade tolerant species (Menalled et al., 1998; Simpson \& Osborn 2006, McNamara et al., 2006; Nichols et al., 2006). In this study all four Acacia species were considered as one of the most lightdemanding species of all exotic species requires maximum light to perform at their best (Mahat, 2007; Kamis et al., 1994, 1995). In relation to that, the great size of the neighboring tree in terms of height, bole diameter and crown size will directly effect and suppress the growth of less superior tree species.

For example, it was reported that the growth performance of Eucalyptus globus could be positively enhanced if it is planted with $A$. mearnsii (Khanna, 1997). The presences of $A$. mearnsii which have the ability to fix $\mathrm{Ni}$ trogen $(\mathrm{N})$ have improved the levels of nitrogen which symbiotically fertilized and enhanced the growth of $E$. globulus. A. mangium and A. auriculiformis were proven to be superior compared to tropical Acacia species such as $A$. crassicarpa and $A$. aulococarpa even though they were perform equally well in a monoculture plantation. Currently, these four species have been planted widely as trial species in other tropical countries such as India, China, Vietnam, Thailand, Indonesia and Malaysia (Indira, 1999). The finding of this study where $A$. mangium did not perform very well in almost all qualitative growth traits except for stem straightness (SS)was similar to the ones reported by Indira (1999) (Table 5). Results from three provenance-progeny trials of $A$. mangium, A. crassicarpa and E. urophylla in Bukidnon province of the southern Philippine island of Mindanao revealed that both $A$. mangium and $A$. crassicarpa had relatively poor stem straightness compared to E. urophylla (Arnold \& Cuevas, 2003). On the other hand, Zhang \& Yang (1996) reported a large variation between families than between provenances in A.crassicarpa when planted in China. It was also observed that even though A.crassicarpa tends to exhibit relatively good stem form, it also possessed large branches compared to such characteristic exhibited by $A$. auriculiformis and A.aulococarpa (Turnbull, 1988; Turnbull et al., 1998). On the contarary, A. aulococarpa in this study produced larger branch size.

Effects of the origin of species on their growth performance have been a major concern over the years. Results from the international provenance and progeny trials of various species have been reported to be positively correlated with their growth performance (Deng et al., 2014 for Cyclocaryapalius; Jansen et al., 2013 for Douglas Fir; Gapare et al., 2012 for Pinusradiata; Lamichhane \& Thapa, 2011 for Azadirachtaindica; Cappa et al., 2010 for Eucalyptus viminalis and Dvorak et al., 1996 for Pinuschiapensis). Similarly, international Acacia tri- 
als for domestification of A. mangium, A. auriculiformis, A. crassicarpa, A. aulococarpa and A. mearnsii showed a wide variation among their provenances collected from all over the world (Anoop et al., 2012 in India; Phi, 2009; Phi et al., 2008 in Vietnam; Dunlop et al., 2005 in South Africa; Arnold et al., 1998 in Philippines; Pinyopusarerk et al., 1996 in Australia; Zhang \& Yang, 1996; Khasa et al., 1995 in Zaire; Kamis et al., 1994 in Malaysia; Harwood \& Williams, 1992 in Malaysia; Minquan \& Yutian, 1991 in China). Provenances tested in this study also showed wide variation among them for all four species tested. A.manguim from SW of Boset WP (PNG) and Captain Billy Road (QLD) provenance outperformed and ranked first as the best performing provenance in terms of height, clear bole height and diameter at breast height (Figure 1). Captain Billy Road is the only provenance of QLD which listed as one of the most top performers in terms of vegetative growth. Bimadebum WP (PNG) and Bensbach WP (PNG) provenances of $A$. crassicarpa recorded in the second and third rank. This again concludes $A$. mangium and A. crassicarpa as the two of the most superior species in terms of growth performance at provenance level. Both provenance of PNG and QLD of A. aulococarpa performed relatively very poor compared to the other provenance and considered as the least favored provenance. However, in another study conducted in Thailand, Keru provenance from PNG of A. aulococarpa was found to grow 4 to 6 times the rate on wood volume basis than the QLD provenances (Turnbull, 1988). The same provenances tested in this study namely Bensbach and Arufi performed better as the most superior provenance when they were planted in Kerala, India (Indira, 1999). Similarly, Bensbach provenance of A. crassicarpa which performed bet-

Table 5. Mean values for qualitative growth traits of four 12 year-old Acacia species.

\begin{tabular}{cccccc}
\hline Species & BF & SS & FA & BS & BA \\
\hline Acacia mangium & $4.44 \pm 0.06^{\mathrm{ab}}$ & $3.77 \pm 0.07^{\mathrm{a}}$ & $3.44 \pm 0.09^{\mathrm{ab}}$ & $3.44 \pm 0.04^{\mathrm{b}}$ & $2.43 \pm 0.04^{\mathrm{a}}$ \\
Acacia auriculiformis & $4.53 \pm 0.06^{\mathrm{a}}$ & $3.72 \pm 0.07^{\mathrm{a}}$ & $3.54 \pm 0.08^{\mathrm{a}}$ & $3.49 \pm 0.04^{\mathrm{ab}}$ & $2.36 \pm 0.11^{\mathrm{a}}$ \\
Acacia crassicarpa & $4.27 \pm 0.06^{\mathrm{b}}$ & $3.47 \pm 0.08^{\mathrm{b}}$ & $3.26 \pm 0.09^{\mathrm{b}}$ & $3.52 \pm 0.04^{\mathrm{ab}}$ & $2.39 \pm 0.04^{\mathrm{a}}$ \\
Acacia aulococarpa & $4.39 \pm 0.07^{\mathrm{ab}}$ & $3.74 \pm 0.04^{\mathrm{a}}$ & $3.53 \pm 0.05^{\mathrm{ab}}$ & $3.57 \pm 0.02^{\mathrm{a}}$ & $2.50 \pm 0.04^{\mathrm{a}}$ \\
\hline
\end{tabular}

Note: $\mathrm{BF}=$ Bole form, $\mathrm{SS}=$ Stem straightness, FA = Forking ability, BS = Branch size, $\mathrm{BA}=$ Branch angle; Values are expressed in Mean \pm Standard Error; Significant differences among species are indicated by different lower case letters $(p<0.05)$.

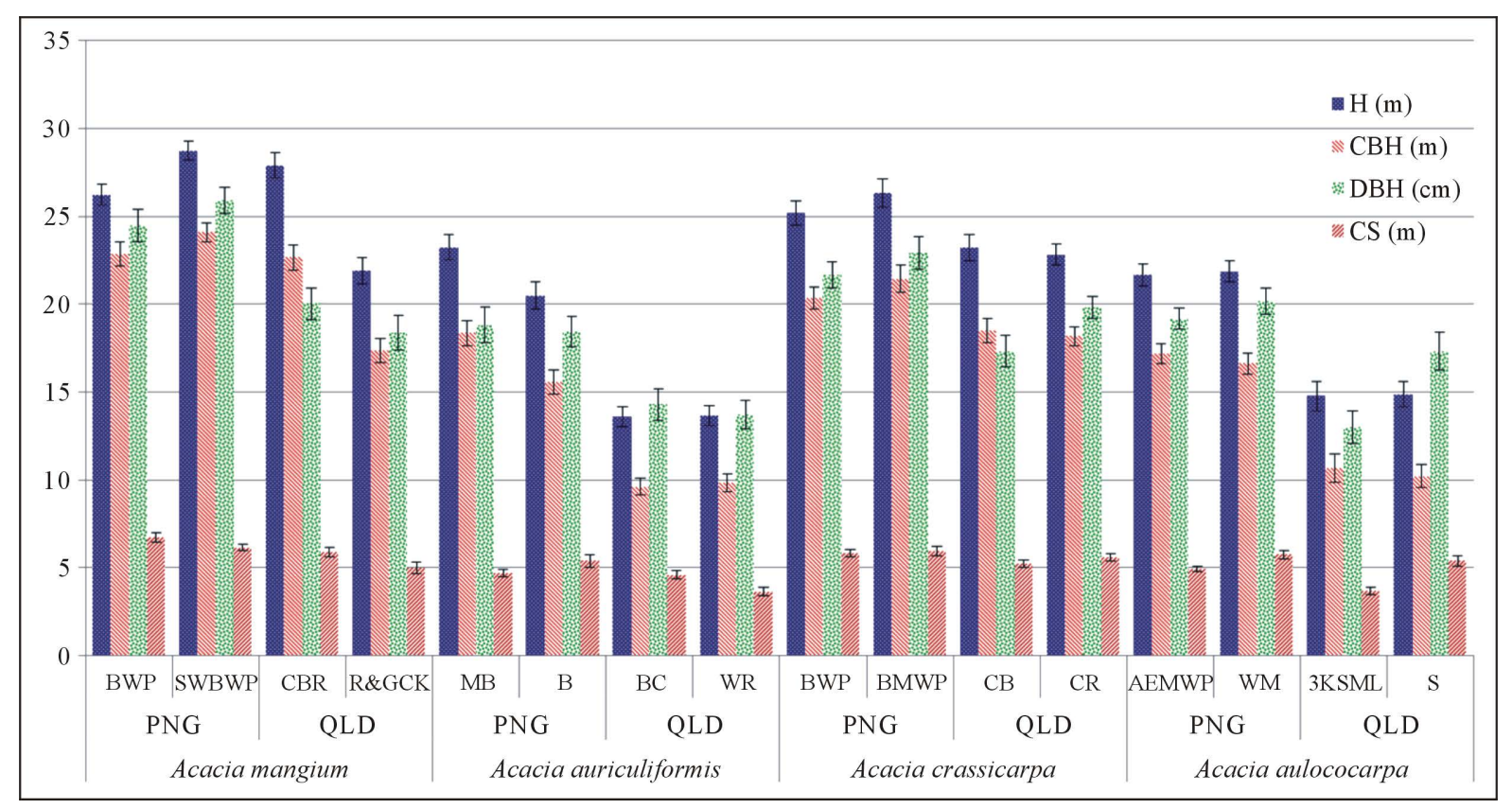

Figure 1. Mean values of quantitative growth traits for provenance within geographic regions of four 12-year-old Acacia species. Note: $\mathrm{H}=$ Height, $\mathrm{CBH}=\mathrm{Clear}$ bole height, $\mathrm{DBH}=$ Diameter at breast height, $\mathrm{CS}=$ Crown size, NS $=$ Number of stem, PNG = Papua New Guinea, QLD = Queensland; Values are expressed in Mean \pm Standard Error; Significant differences among species are indicated by different lower case letters $(p<0.05)$. 



Figure 2. Mean values of quantitative growth traits for progenies within provenance and geographic regions of 12-year-old Acacia mangium, Acacia auriculiformis, Acacia crassicarpa and Acacia aulococarpa. 
ter in this study failed to perform in India. In contrast, Buiso and Isago Arimu provenance outperformed Bensbach provenance in term of height and girth. As another example, Wipim provenance which grew better than the local Indonesia provenance recorded as the most slowly growing provenance in India (Indira, 1999; Turvey, 1996). The outcome of this trials suggest that one selected superior provenance in a certain environmental condition may or may not suited and perform similarly at another.

Means of the traits for progenies in each species and provenance and are presented in Figure 2. Progenies from different seed lot showed growth variation in terms of quantitative as well as their qualitative traits. Performance of progenies from different provenance and species was inconsistent. Growth performance of progenies was ranked according to their cumulative score based on the cluster analyses of similarity of mean values. Performance of CG 1854 and CG 1855 both from SW of Boset WP provenence recorded as 2 of the best performing progenies followed by KN 000107 of Bensbach WP provenance for A. mangium. BVG 00835 and MM 001016 from WP Morehead and Arufi E. Morehead WP respectively recorded as the top performers of $A$. aulococarpa and both ranked in the first place. BVG 00860 and BVG 00834 progenies also from WP Moreheadprovenance listed as third and fourth ranking. Whereas for $A$. crassicarpa, the order of excellence with regards to progenies cumulative growth traits ranking was BVG 2609 (Bensbach WP) $>$ GJM 1135 (Chilli Beach) > BVG 2748 (Bimadebum WP). All of the best performing progenies of A. mangium, A. crassicarpa and A. aulococarpa are originated from PNG region. JSL 363 of Wenlock River is the only best performing progenies from QLD region of A.auriculiformis followed by BVG 2657 and BVG 2641 progenies of Bansbach provenance from PNG region. Those individuals identified as candidate trees of each progenies were recorded and analyses according to their ranking and three most superior individual trees for each species were selected for further vegetative propagation.

\section{Conclusion}

The high significant differences among provenance and progeny level indicate that quantitative and qualitative growth traits could be used as good indicator and selection criterion to select improved material for breeding purpose. Selection of a good genotype for plantation and establishment of seed orchards supposed to be based on the early trials using seed sources from wide range of genetic base. Poor selection method in forest plantation species will lead to great loss in economic income of a public or private sectors. For instance, development of seed production area and seed orchard of A. mangium in Sabah and Subanjeriji, Indonesia using genetic material comes from very narrow genetic base have resulted in production of poor quality seeds (Turvey, 1995; Turnbull et al., 1998). As a conclusion, this was designed to evaluate the genetic variation among species, region, provenance and progeny in terms of quantitative and qualitative growth traits by establishing a provenance/progeny growth trial at Kampung Aur Gading, Kuala Lipis, Pahang. All the variation sources were statistically significant for most of the studied traits especially in the quantitative growth traits. Information gathered in this study regarding selection of Acacia genotypes can be used as guideline for field establishment using Australian seed sources in Malaysia. It will have a practical implication for establishment and management of plantation forest of Acacia species in Malaysia with selected seed sources as well as improved planting material to improve their productivity.

\section{References}

Anoop, E. V., Ajayghosh, V., MuhammedShabab, P., \& Aruna, P. (2012). Provenance Variation in Wood Anatomical Properties of Selected Acacia Species. Journal of Indian Academy Wood Science, 9, 96-100. http://dx.doi.org/10.1007/s13196-012-0072-5

Arnold, R. J., \& Cuevas, E. (2003). Genetic Variation in Early Growth, Stem Straightness and Survival in Acacia crassicarpa, A. mangium and Eucalyptus urophylla in Bukbdnon Province, Philippines. Journal of Tropical Forest Science, 15, $332-351$

Arnold, R. J., Gonzales, A., \& Abarquez, A. (1998). Domestication of Exotic Acacia Species in Bukidnon Province, Philippines. In: J. W. Turnbull, H. R. Crompton, \& K. Pinyopusarerk (Eds.), Recent Developments in Acacia Planting: Proceedings of an International Workshop (pp. 136-142). Hanoi: Australian Centre for International Agricultural Research.

Banerjee, P. (2013). Rapid in Vitro Propagation of Acacia auriculiformis on Solid and Liquid Media: Role of Organic Additive, Antioxidant and Plant Growth Regulators. Cibtech Journal of Bio-Protocols, 2, 39-49.

Butcher, P., \& Southerton, S. (2007). Chapter 15: Marker Assisted Selection in Forestry Species. In E. P. Guimaraes, J. Ru- 
ane, B. D. Scherf, A. Sonnino, \& J. D. Dargie (Eds.), Marker Assisted Selection: Current Status and Future Perspectives in Crop, Livestock, Forestry and Fish. Rome: Food and Agriculture Organization of the United Nation (FAO).

Cappa, E. P., Pablo, S., Pathauer, P. S., \& Lopez, G. A. (2010). Provenance Variation and Genetic Parameters of Eucalyptus viminalis in Argentina. Tree Genetics and Genomes, 6, 981-994. http://dx.doi.org/10.1007/s11295-010-0307-9

Cornelius, J. (1994). The Effectiveness of Plus-Tree Selection for Yield. Forest Ecology and Management, 67, 23-34. http://dx.doi.org/10.1016/0378-1127(94)90004-3

Cotterill, P. P., \& Dean, C. A. (1990). Successful Tree Breeding with Index Selection (88 p). Australia: CSIRO.

Deng, B., Fang, S., Yang, W., Tian, Y., \& Shang, X. (2014). Provenance Variation in Growth and Wood Properties of Juvenile Cyclocaryapaliurus. New Forests, 45, 625-639. http://dx.doi.org/10.1007/s11056-014-9424-X

Dunlop, R. W., Resende, M. D. V., \& Beck, S. L. (2005). Early Assessment of First Year Height Data from Five Acacia Mearnsii (Black Wattle) Sub-Populations in South Africa Using Reml/Blup. Silvae Genetica, 54, 4-5.

Dvorak,W. S., Donahue, J. K., \& Vasquez, J. A. (1996). Provenance and Progeny Results for the Tropical White Pine, Pinuschiapensis, at Five and Eight Years of Age. New Forests, 12, 125-140.

Gadow, V. K., \& Bredenkamp, B. V. (1992). Forest Management. Pretoria: Academica.

Gapare, W. J., Ivkovic, M., Dutkowski, G. W., Spencer, D. J., Buxton, P., \& Wu, H. X. (2012). Genetic Parameters and Provenance Variation of Pinusradiata D. Don. "Eldridge Collection" in Australia 1: Growth and Form Traits. Tree Genetics and Genomes, 8, 391- 407. http://dx.doi.org/10.1007/s11295-011-0449-4

Girijashankar, V. (2011). Micropropagation of Multipurpose Medicinal Tree Acacia auriculiformis. Journal of Medicinal Plant Research, 5, 462-466.

Griffin, A., Kumar, S. M., \& Shukor, N. A. A. (2014). In Vitro Regeneration of Acacia crassicarpa A. Cunn Ex Benth through Organogenesis from Juvenile Sources. Journal of Food, Agriculture and Environment, 12, 375-382.

Harwood, C. E., \& Williams, E. R. (1992). A Review of Provenance Variation in Growth of Acacia mangium. In L. T. Carron, \& K. M. Aken (Eds.), Breeding Technologies for Tropical Acacias (No. 37, pp. 22-30). Canberra: ACIAR Proceedings.

Indira, E. P. (1999). Provenance Trials in Acacia (p. 21). Kerala Forest Research Institute (KFRI) Research Report 171.

Ismail, H., Shukor, N. A. A., Aziah, M. Y., Nor, H. H., Fadhilah, Z., Nazirah, A., \& Siti, S. A. R. (2012). In Vitro Shoot Induction of Acacia auriculiformis from Juvenile and Mature Sources. Journal of Biotechnology and Pharmaceutical Research, 3, 88-93.

Jahan, M. S., Sabina, R., \& Rubaiyat, A. (2008). Alkaline Pulping and Bleaching of Acacia auriculiformis Grown in Bangladesh. Turkish Journal of Agriculture and Forestry, 32, 339-347.

Jansen, k., Sohrt, J., Kohnle, U., Ensminger, I., \& Gessler, A. (2013). Tree Ring Isotopic Composition, Radial Increment and Height Growth Reveal Provenance-Specific Reactions of Douglas-Fir Towards Environmental Parameters. Trees, 27, 3752. http://dx.doi.org/10.1007/s00468-012-0765-9

Kamis, A., Nor Aini, A. S., \& Senin, A. L. (1995). Two Year Performance of Acacia crassicarpa Provenance at Serdang, Malaysia. Journal of Tropical Agricultural Sciences, 18, 177-181.

Kamis, A., Nor Aini, A. S., Adjers, G., Bhumibhamon, S., Pan, F. J., \& Venkateswarlu, P. (1994). Performance of Acacia auriculiformis Provenance at 18 Months of Four Sites. Journal of Tropical Forest Science, 7, 251-261.

Kha, L. D. (2003). Chon Tao going vanhan Going cho mot so loai cay trong rung chuyeu o Viet Nam. Ha Noi: Agriculture Publishing House, 292 p. (In Vietnamese)

Khanna, P. K. (1997). Comparison of Growth and Nutrition of Young Monocultures and Mixed Stands of Eucalyptus globulus and Acacia mearnsii. Forest Ecology Management, 94, 105-113. http://dx.doi.org/10.1016/S0378-1127(96)03971-0

Khasa, P. D., Li, P., Vallee, G., Magnussen, S., \& Bousquet, J. (1995). Early Evaluation of Racosperma auriculiforme and $R$. mangium Provenance Trials on Four Sites in Zaire. Forest Ecology and Management, 78, 99-103. http://dx.doi.org/10.1016/0378-1127(95)03593-6

Lamichhane, D., \& Thapa, H. B. (2011). International Provenance Trial of Neem (Azadirachta indica) in the Terai Region of Nepal. Agroforestry Systems, 81, 37-43. http://dx.doi.org/10.1007/s10457-010-9353-4

Logan, A. F. (1987). Australian Acacias for Pulpwood. In J. W. Turnbull (Ed.), Australian Acacias in Developing Countries (No. 16, pp. 89-94). Canberra: ACIAR Proceedings.

Luangviriyasaeng, V., \& Pinyopusarerk, K. (2002). Genetic Variation in Second Generation Progeny Trial of Acacia auriculiformis in Thailand. Journal of Tropical Forest Science, 14, 131-144.

Mahat, M. N. (2007). Growth Performance and Genetic Variation of Four Acacia Species Planted in Pahang, Malaysia (298 p). Doctoral Thesis, Putra: Universiti Putra Malaysia. 
McNamara, S., Tinh, D. V., Erskine, P. D., Lamb, D., Yates, D., \& Brown, S. (2006). Rehabilitating Degraded Forest Land in Central Vietnam with Mixed 495 Native Species Plantings. Forest Ecology and Management, 233, 358-365. http://dx.doi.org/10.1016/j.foreco.2006.05.033

Menalled, F. D., Kelty, M. J., \& Ewel, J. J. (1998). Canopy Development in Tropical Tree 500 Plantations: A Comparison of Species Mixtures and Monocultures. Forest Ecology and Management, 104, 249-263. http://dx.doi.org/10.1016/S0378-1127(97)00255-7

Minquan, Y., \& Yutian, Z. (1991). Results from a Four-Year-Old Tropical Acacia Species/Provenance Trial in Hainan Island, China. In J. W. Turnbull (Ed.), Advances in Tropical Acacia Research (No. 35). Bangkok: ACIAR Proceedings.

Mishra, D. K. (2009). Selection of Candidate plus Phenotypes of Jatropha curcas L. Using Method of Paired Comparisons. Biomass and Bioenergy, 33, 542-545. http://dx.doi.org/10.1016/j.biombioe.2008.08.004

Mittal, A., Agarwal, R., \& Gupta, S. C. (1989). In Vitro Development of Plantlets from Axillary Buds of Acacia auriculiformis- A Leguminous Tree. Plant Cell, Tissue and Organ Culture, 19, 65-70. http://dx.doi.org/10.1007/BF00037777

Nghia, N. H. (2003). Phattriencacloai Keo Acacia o Viet Nam (121 p). Ha Noi: Agriculture Publishing House. (In Vietnamese)

Nichols, J. D., Bristow, M., \& Vanclay, J. K. (2006). Mixed Species Plantations: Prospects and Challenges. Forest Ecology and Management, 233, 383-390. http://dx.doi.org/10.1016/j.foreco.2006.07.018

Nor Aini, A. S., Kamis, A., Mansor, M. R., \& Senin, A. L. (1994). Provenance Trial of Acacia auriculiformis in Peninsular Malaysia: 12-Month Performance. Journal of Tropical Forest Science, 6, 249-256.

Otsamo, A. O., Nikels, D. G., \& Vuokko, R. H. O. (1996). Species and Provenance Variation of Candidate Acacias for Afforestation of Imperata cylindrica Grasslands in South Kalimantan, Indonesia. In M. J. Dieters, A. C. Matheson, C. E. Harwoodand, \& S. M. Walker (Eds.), Tree Improvement for Sustainable Tropical Forestry (pp. 46-50). Queensland: QFRI-IUFRO.

Phi, H. H. (2009). Genetic Improvement of Plantation Grown Acacia auriculiformis for Sawn Timber Production (54 p). Doctoral Thesis, Uppsala: Swedish University Agricultural Sciences.

Phi, H. H., Jansson, G., Harwood, C., Hannrup, B., \& Thinh, H. H. (2008). Genetic Variation in Growth, Stem Straightness and Branch Thickness in Clonal Trials of Acacia auriculiformis at Three Contrasting Sites in Vietnam. Forest Ecology and Management, 255, 156-167. http://dx.doi.org/10.1016/j.foreco.2007.09.017

Rao, N. J. (1992). Forest Genetics in Tamil Nadu. Indian Forester, 118, 28-35.

Renuka, C. (2001) Maintenance of Seed Stands and Species Trial Plots of Rattans. KFRI Research Report No. 222.

Senin, A. L., Hamid, H. A., Kusno, M. A., Abdu, A., \& Ismail, M. K. (2011). Comparative Growth of 11 Year Old Acacia aulococarpa A. Cunn. Ex. Benthfrom Four Provenances. Research Journal of Forestry, 5, 154-161. http://dx.doi.org/10.3923/rjf.2011.154.161

Shukla, S. R., Rao, R. V., Sharma, S. K., Kumar, P., Sudheendra, R., \& Shashikala, S. (2007). Physical and Mechanical Properties of Plantation-Grown Acacia auriculiformis of Three Different Ages. Australian Forestry, 70, 86-92. http://dx.doi.org/10.1080/00049158.2007.10675007

Simpson, J., \& Osborne, D. (2006). Performance of Seven Hardwood Species Underplanted to Pinus elliottii in South-East Queensland. Forest Ecology and Management, 233, 303-308. http://dx.doi.org/10.1016/j.foreco.2006.05.021

Steele, P. H. (1984). Factors Determining Lumber Recovery in Sawmilling (10 p). Madison: United States Department of Agri- culture, Forest Service, Forest Products Laboratory, General Technical Report-FPL-39.

Strauss, S. H., Lande, R., \& Namkoong, G. (1992). Limitation of Molecular Marker-Aided Selection in Forest Tree Breeding. Canadian Journal of Forest Research, 22, 1050-1061. http://dx.doi.org/10.1139/x92-140

Turnbull, J. W. (1988). Australian Acacias in World Forestry (15 p). Albury: Paper at the Bicentennial Forestry Conference.

Turnbull, J. W., Midgley, S. J., \& Cossalter, C. (1997). Tropical Acacias Planted in Asia: An Overview of Recent Developments in Acacias Planting. In J. W. Turnbull, et al., (Eds.), Recent Developments in Acacia Planting (No. 82, pp. 14-18). Canberra: ACIAR Proceedings.

Turnbull, J. W., Midgley, S. J., \& Cossalter, C. (1998). Tropical Acacias Planted in Asia: An Overview. In J. W. Turnbull, H. R. Crompton, \& K. Pinyopusarerk (Eds.), Recent Developments in Acacia Planting (pp. 14-28). Canberra: ACIAR Proceedings.

Turvey, N. D. (1996). Growth at Age 30 Months of Acacia and Eucalyptus Species Planted in Imperata Grasslands in Kalimantan Selatan, Indonesia. Forest Ecology and Management, 82, 185- 195. http://dx.doi.org/10.1016/0378-1127(95)03665-2

Williams, E. R., \& Matheson, A. C. (1994). Experimantal Design and Analysis for Use in Tree Improvement (174 p). Australia: CSIRO Publication Service. 
Wright, J. W. (1976). Introduction to Forest Genetics (p. 463). New York: Academic.

Zhang, F. Q., \& Yang, M. Q. (1996). Comprehensive Selection of Provenences and Families of Acacia crassicarpa. In M. J. Dieters, A. C. Matheson, C. E. Harwood, \& S. M. Walker (Eds.), Tree Improvement for Sustainable Tropical Forestry (pp. 401-403). Queensland: QFRI-IUFRO.

Zobel, B. J., \& Talbert, J. (1984). Applied Forest Tree Improvement (505 p). New York: John Wiley.

Submit or recommend next manuscript to SCIRP and we will provide best service for you:

Accepting pre-submission inquiries through Email, Facebook, Linkedin, Twitter, etc A wide selection of journals (inclusive of 9 subjects, more than 200 journals)

Providing a 24-hour high-quality service

User-friendly online submission system

Fair and swift peer-review system

Efficient typesetting and proofreading procedure

Display of the result of downloads and visits, as well as the number of cited articles

Maximum dissemination of your research work

Submit your manuscript at: http://papersubmission.scirp.org/ 